\title{
PENGARUH PENAMBAHAN PENDINGIN AIR PADA TRANSFORMATOR DAYA UNTUK PEMBEBANAN
}

\author{
Soecipto Soewono'), John Paulus Pantouw ${ }^{2)}$, Prabowo ${ }^{3)}$ \\ Teknik Elektro, Sekolah Tinggi Teknik-PLN \\ 'stsoewono@yahoo.com; \\ 2johnpp30@gmail.com \\ 3Pbow010@gmail.com
}

\begin{abstract}
Abstrak : Transformator daya adalah salah satu peralatan penting di sistem tenaga listrik. Transformator daya merupakan peralatan dengan investasi terbesar pada sebuah Gardu Induk transmisi dan distribusi. Saat ini, penggunaan transformator daya pada Gardu Induk Marunda rata-rata telah mencapai $80 \%$ dari beban pengenal. Maka membutuhkan pendinginan transformator yang maksimal, untuk menahan laju kenaikan temperatur kumparan dan minyak. Hasil penelitian diperoleh dengan penambahan pendingin air pada transformator daya dapat meredam panas akibat temperatur lingkungan yang tinggi. Dari hasil penelitian diperoleh penurunan temperatur sebesar $3^{\circ} \mathrm{C}$, Sehingga bisa digunakan untuk menambah pembebanan transformator sebesar 2,51 MW. Sedangkan pemakaian air perhari adalah 2,052 $\mathrm{m}^{3}$.
\end{abstract}

Kata kunci : Transformator, Temperatur, Pendingin Transformator

Abstract : Power transformers are one of the important equipment in the electric power system. Power transformers are devices with the largest investment in a transmission and distribution substations. Currently, the use of power transformers at Marunda substations on average has reached $80 \%$ of rated load. Then require maximum of cooling transformers, to restrain the rate of the winding and oil temperature rise. Result of the research were obtained with the addition of water cooling at power transformers can be reduce the heat due to the high ambient temperatures. The results showed a decrease in temperature of $3^{\circ} \mathrm{C}$, so can be used to add transformers loading of 2,51 MW. While of water consumption was $2,052 \mathrm{~m}^{3}$ per day.

Keywords : Transformer, Temperature, Cooling of Transformer

\section{PENDAHULUAN}

Transformator Daya adalah salah satu peralatan penting di jaringan tenaga listrik. Transformator Daya merupakan peralatan yang mempunyai investasi paling besar di sebuah gardu induk transmisi dan distribusi. Kinerja yang baik pada transformator adalah penting untuk menunjang operasi sistem tenaga listrik. Kegagalan proteksi pada transformator merupakan kerugian yang besar dalam segi kehandalan dan biaya dari penyaluran tenaga listrik. Salah satu faktor utama dari pemantauan kondisi operasi transformator adalah temperatur internal, khususnya temperatur pada kumparan dan temperatur minyak atas.
Temperatur yang tinggi dapat berakibat mempengaruhi penuaan isolasi dan masa guna transformator tersebut. Nilai-nilai pada temperatur kumparan dan minyak dapat memberikan diagnosa pada kondisi transformator dan untuk indikasi adanya kemungkinan kelainan, mengurangi resiko kerusakan yang fatal dan menghindari masalah operasi darurat. ${ }^{[1]}$

Transformator daya yang di rancang pada tahun 1990-an untuk didesain pada lingkungan bertemperatur $20^{\circ} \mathrm{C}$, sementara apabila transformator tersebut dioperasikan di daerah Jakarta dan sekitarnya maka temperatur lingkunganya adalah sekitar $30^{\circ} \mathrm{C}-36^{\circ} \mathrm{C}$. Saat beroperasi temperatur dari transformator akan meningkat, hal itu dipengaruhi oleh 
pembebanan dari dalam transformator itu sendiri dan temperatur dari lingkungan sekitar transformator tersebut berada.

Gardu Induk Marunda memiliki 3 buah transformator tenaga. Pembebanan dari masing-masing transformator sudah melebihi $80 \%$ dari rating beban. Pada Gardu Induk Marunda untuk kondisi darurat dalam hal gangguan pada salah satu transformator, beban akan dipindahkan ke transformator yang tidak terganggu. Sehingga pada transformator yang tidak terganggu akan menampung beban lebih dari transformator akibat adanya gangguan tersebut. Maka pemantauan secara rutin terhadap temperatur transformator sangat penting untuk memastikan kehandalan penyaluran tenaga listrik.

Dengan uraian tersebut, maka penelitian akan membahas tentang Analisis Pengaruh Penambahan Pendingin Air Pada Transformator Daya Untuk Penambahan Pembebanan.

\section{Tujuan Penelitian :}

- Meningkatkan kemampuan transformator dalam melayani pembebanan dengan adanya penambahan pendingin tersebut.

- Menentukan nilai penambahan pembebanan terhadap perubahan temperatur pada kumparan dan minyak transformator dengan adanya penambahan pendingin tersebut.

- Mengetahui karakteristik temperatur pada kumparan dan minyak dengan adanya penambahan pendingin tersebut.

Berdasarkan penelitian Rukiye Karadag tahun 2012, menjelaskan bahwa distribusi temperatur diperhitungkan, sangat penting untuk menentukan komponen didalam tahapan desain pada transformator dan lamanya operasi, karena temperatur diatas batas thermal akan merusak komponen transformator. Model thermal digunakan untuk memprediksi sebelum operasi sebenarnya. Dalam penelitian ini, model tiga dimensi berdasarkan Metode Element Finite diterapkan untuk memperkirakan distribusi temperatur didalam tiga fasa, gas sf6, dan pendingin transformator daya. Hasil model ini dapat memprediksi distribusi temperatur pada lokasi terdiskreditkan tertentu didalam transformator dengan akurat menggunakan software ANSYS 13. Selanjutnya pada penelitian Min-gu Kim, Sang Moon Cho, Joong-Kyoung tahun 2013, Menyajikan prediksi dan eksperimen pada kinerja radiator pada transformator pendingin ONAN dan ODAN. Menggunakan simulasi ANSYS CFD (Computational Fluid Dynamics) diketahui kapasitas pendinginan ODAN maksimum lebih baik 20,1 \% dibandingkan dengan ONAN.

\section{Hipotesis}

1. Adanya penambahan pendingin air pada transformator daya, dapat untuk menambah pembebanan.

2. Ada perbedaan karakteristik temperatur kumparan dan minyak pada transformator daya terhadap adanya penambahan pembebanan dan penambahan pendingin air pada transformator daya.

\section{LANDASAN TEORI}

Isolasi yang biasa dipakai dalam transformator bisa cepat sekali menjadi buruk apabila dikenai panas dengan temperatur diatas kelas isolasinya secara terus menerus. Temperatur diatas kekuatan kelas isolasinya ini hanya dapat ditahan dalam selang waktu yang relatif singkat, namun efek kumulatif dan hubungan antara temperatur dengan waktu tidak dapat ditentukan. Kenaikan temperatur pada kumparan dan minyak transformator dirancang untuk pemakaian dengan ketinggian tidak lebih dari 1000 meter diatas permukaan laut (mdpl). Pada transformator yang menggunakan media pendingin air, maka temperatur air tidak boleh lebih dari $25^{\circ} \mathrm{C}$. Untuk transformator yang menggunakan media pendingin udara, maka temperatur udaranya tidak boleh lebih dari $40^{\circ} \mathrm{C}$ dan tidak boleh dibawah $-25^{\circ} \mathrm{C}$ untuk pemasangan luar dan tidak boleh dibawah $-5^{\circ} \mathrm{C}$ untuk pemasangan dalam. Sebagai tambahan untuk pendinginan dengan menggunakan udara, temperaturnya tidak melebihi rata-rata $30^{\circ} \mathrm{C}$ untuk satu hari. ${ }^{6]}$ 
Perpindahan panas konduksi adalah proses perpindahan panas dari daerah bersuhu tinggi ke daerah bersuhu rendah dengan melalui medium, tanpa disertai perpindahan medium tersebut. Contoh perpindahan panas melalui sebatang besi. Perpindahan panas konduksi dapat dinyatakan dengan persamaan ${ }^{[4]}$.

$q=-k A \frac{d T}{d x}$

$q$ = Laju perpindahan panas, $\mathrm{W}$

$A=$ Luas perpindahan panas, $\mathrm{m}^{2}$

$\frac{d T}{d x}=$ Gradien temperatur pada penampang, atau laju perubahan temperatur arah sumbu $\mathrm{x}$ terhadap jarak dalam arah aliran panas $\mathrm{x}$.

Hukum pendinginan Newton menyatakan bahwa laju perubahan pendinginan temperatur suatu benda sebanding dengan perbedaan antara temperatur sendiri dan temperatur lingkungan (yaitu temperatur sekitarnya).

Perpindahan panas dari permukaan padat ke fluida yang ada disekitarnya terjadi secara konveksi dan dinyatakan dengan persamaan ${ }^{[4]}$ :

$q=h A\left(T_{w-} T_{f}\right)$

$q=$ Laju perpindahan panas, $\mathrm{W}$

$h=$ Koefisien perpindahan panas, $\mathrm{W}$ $/ \mathrm{m}^{2}{ }^{\circ} \mathrm{C}$ atau $\mathrm{kW} / \mathrm{m}^{2}{ }^{\circ} \mathrm{C}$.

$A=$ Luas perpindahan panas, $\mathrm{m}^{2}$

$T_{w}=$ Temperatur permukaan, ${ }^{\circ} \mathrm{C}$

$T_{f}=$ Temperatur rata-rata fluida, ${ }^{\circ} \mathrm{C}$

Koefisien perpindahan panas tergantung dari sifat bahan fluida dan kecepatan fluida tersebut. Pertimbangan perpindahan panas dari fluida $A$ ke fluida $B$ melalui dinding pemisah $x$, dan konduktivitas thermal $k$, diperlihatkan pada gambar 1.2

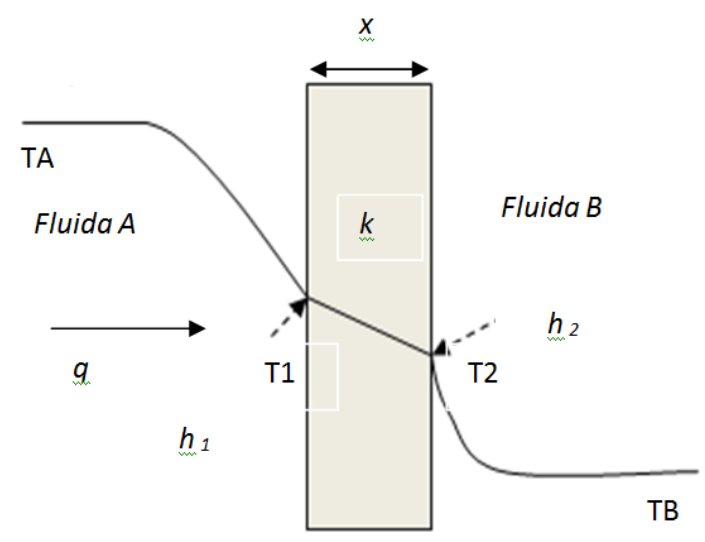

Gambar 1.1 Variasi temperatur untuk perpindahan panas dari suatu fluida ke fluida yang lain melalui dinding pembagi.

Secara analogi persamaan dapat ditulis sebagai :

$q=U\left(t_{A}-t_{B}\right)$

atau,

$$
\begin{aligned}
q & =U A\left(t_{A}-t_{B}\right) \\
\frac{1}{U} & =\left(\frac{1}{h_{1}}+\frac{x}{k}+\frac{1}{h_{2}}\right) \\
U & =\frac{1}{\frac{1}{h_{1}}+\frac{x}{\mathrm{k}}+\frac{1}{h_{2}}}
\end{aligned}
$$

$\mathrm{U}=$ Koefisien perpindahan panas menyeluruh (Overall Heat Transfer Coefficient), $\mathrm{W} / \mathrm{m}^{2} .{ }^{\circ} \mathrm{C}$

Koefisien perpindahan panas menyeluruh adalah merupakan aliran panas menyeluruh sebagai hasil gabungan proses konduksi dan konveksi.

\section{METODE PENELITIAN}

Penelitian ini merupakan penelitian deskriptif kuantitatif, dengan pendekatan Longitudinal Studies. Dalam penelitian ini variabel bebas (Independent Variables) dan variabel terikat (Dependent Variables) dinilai secara simultan dengan pengukuran pada satu waktu terhadap faktor penambahan pendingin. Maka akan diperoleh efek penambahan pendingin air pada transformator terhadap temperatur kumparan dan minyak pada kondisi 
tertentu, Sehingga dapat menentukan hubungan antara faktor penambahan pendingin dan dampak terhadap transformator. Variabel yang diteliti terdiri dari variabel bebas, variabel terikat, dan variabel pengganggu. Variabel bebas, terdiri dari : temperatur air, lama penggunaan dan jumlah air yang digunakan per hari serta jenis pembebanan transformator (dalam per- unit). Variabel terikat terdiri dari : temperatur pada minyak dan kumparan, penambahan pembebanan. Variabel pengganggu terdiri dari : temperatur lingkungan, kecepatan angin, kelembaban.

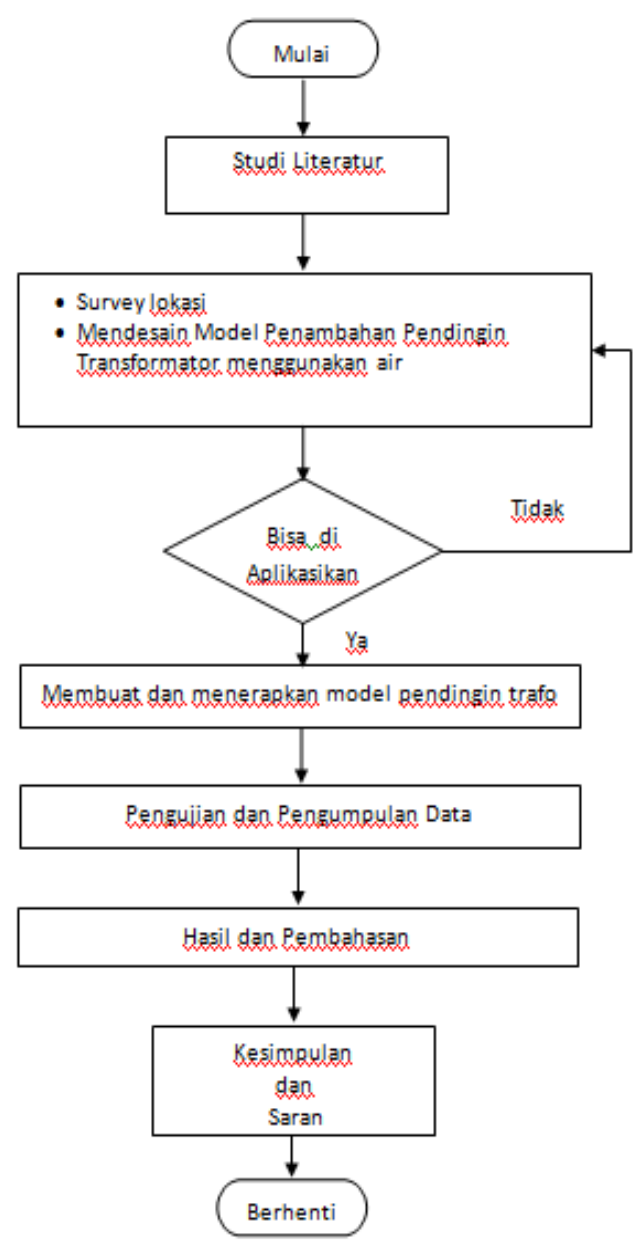

Gambar 1.2 Diagram Alir Penelitian

\section{HASIL DAN PEMBAHASAN}

Pada penelitian ini menggunakan data transformator unit 3 sebagai objek yang akan diteliti. Transformator unit 3 pada Gardu Induk Marunda keluaran
UNINDO tahun pembuatan 1994. Dengan data sebagai berikut : Transformator 3 fasa, (60 MVA, 150 / 20 kV, $50 \mathrm{~Hz}$ ), Type : TTHRv, Sistem pendingin : ONAN/ONAF, Kenaikan temperatur kumparan dan minyak bagian atas (garansi) : $58^{\circ} \mathrm{C}$ dan $53^{\circ} \mathrm{C}$, Rugi-rugi total / rugi-rugi tanpa beban : 150,364 kW / 27,75 kW, Standar IEC 76 - 1976, Pemasangan : Luar, Jenis minyak : Minyak Mineral Shell Diala B, Kelas Isolasi : A.

\subsection{Hasil Pengukuran Tanggal 08 November 2016}

Berikut adalah Data hasil pengukuran transformator unit 3 pada tanggal 08 November 2016 dengan pendingin air dioperasikan.

\begin{tabular}{|c|c|c|c|c|c|c|c|c|c|c|c|c|}
\hline & 1.00 & \begin{tabular}{|l|l}
2.00 \\
\end{tabular} & 3.00 & 4.00 & \begin{tabular}{|l|l}
5.00 \\
\end{tabular} & 6.00 & 7.00 & 8.00 & \begin{tabular}{|l}
9.00 \\
\end{tabular} & 10.00 & 11.00 & 12.00 \\
\hline $\begin{array}{l}\text { Temp. } \\
\text { hingkongan } \\
\left({ }^{\circ} \mathrm{C}\right)\end{array}$ & 28.0 & 27.0 & 26.5 & 26.5 & 27.0 & 27.0 & 31.5 & 33.0 & 34.3 & 35.0 & 36.5 & 35.0 \\
\hline $\begin{array}{c}\text { Kumparan } \\
\left({ }^{\circ} \mathrm{C}\right)\end{array}$ & 63 & 62 & 61 & 60 & 59 & 58 & 61 & 63 & 66 & 69 & 70 & 69 \\
\hline $\begin{array}{l}\text { Minyak } \\
\left({ }^{\circ} \mathrm{C}\right)\end{array}$ & 53 & 52 & 52 & 51 & 50 & 50 & 53 & 53 & 54 & 57 & 58 & 57 \\
\hline $\begin{array}{l}\text { Beban } \\
\text { (MW })\end{array}$ & 45.23 & \begin{tabular}{|l}
44.24 \\
\end{tabular} & 43.80 & 42.15 & $\begin{array}{l}41.85 \\
\end{array}$ & 42.13 & 42.57 & 46.01 & \begin{tabular}{|ll}
48.30 \\
\end{tabular} & 49.57 & 50.50 & 47.17 \\
\hline $\begin{array}{l}\text { Beban } \\
(2, u)\end{array}$ & 0.770 & 0.754 & 0.746 & 0.718 & 0.713 & 0.718 & 0.725 & 0.784 & 0.823 & 0.844 & 0.860 & 0.803 \\
\hline
\end{tabular}

\begin{tabular}{|c|c|c|c|c|c|c|c|c|c|c|c|c|}
\hline & 13.00 & \begin{tabular}{|l|}
14.00 \\
\end{tabular} & \begin{tabular}{|l}
15.00 \\
\end{tabular} & \begin{tabular}{|l}
16.00 \\
\end{tabular} & \begin{tabular}{|l}
17.00 \\
\end{tabular} & 18.00 & 199.00 & 20.00 & 21.00 & 22.00 & 23.00 & 24.00 \\
\hline $\begin{array}{l}\text { Temp. } \\
\text { Lingkngan } \\
\left({ }^{\circ} \mathrm{C}\right)\end{array}$ & 33.5 & \begin{tabular}{|l|} 
\\
\end{tabular} & \begin{tabular}{|l}
4.5 \\
\end{tabular} & \begin{tabular}{|l|l} 
& \\
\end{tabular} & 31.5 & 30.5 & \begin{tabular}{|l|}
30.0 \\
\end{tabular} & 29.0 & 29.0 & 29.0 & \begin{tabular}{|l|l|} 
& 28.5
\end{tabular} & 28.5 \\
\hline $\begin{array}{l}\text { Kumparan } \\
\left({ }^{\circ} \mathrm{C}\right)\end{array}$ & 70 & 71 & 71 & 71 & 70 & 69 & 68 & 67 & 66 & 66 & 65 & 64 \\
\hline $\begin{array}{l}\text { Minyaks } \\
\left({ }^{\circ} \mathrm{C}\right)\end{array}$ & 58 & 59 & 59 & 59 & 59 & 58 & 57 & 56 & 56 & 55 & 55 & 54 \\
\hline $\begin{array}{l}\text { Bebban } \\
\text { (MW) }\end{array}$ & 50.33 & 51.83 & \begin{tabular}{|l}
51.83 \\
\end{tabular} & \begin{tabular}{|l}
51.67 \\
\end{tabular} & 52.50 & \begin{tabular}{|l}
48.67 \\
\end{tabular} & 50.50 & \begin{tabular}{|l|l} 
& 51.09
\end{tabular} & \begin{tabular}{|l}
$\mid 50.86$ \\
\end{tabular} & \begin{tabular}{|l|}
50.07 \\
\end{tabular} & \begin{tabular}{|l}
$\mid 48.00$ \\
\end{tabular} & $\mid 45.51$ \\
\hline $\begin{array}{l}\text { Reban } \\
(2, u)\end{array}$ & 0.857 & 0.883 & 0.883 & $\mid 0.880$ & 0.894 & 0.829 & 0.860 & 0.870 & 0.866 & 0.853 & 0.818 & \begin{tabular}{|l|l} 
\\
\end{tabular} \\
\hline
\end{tabular}

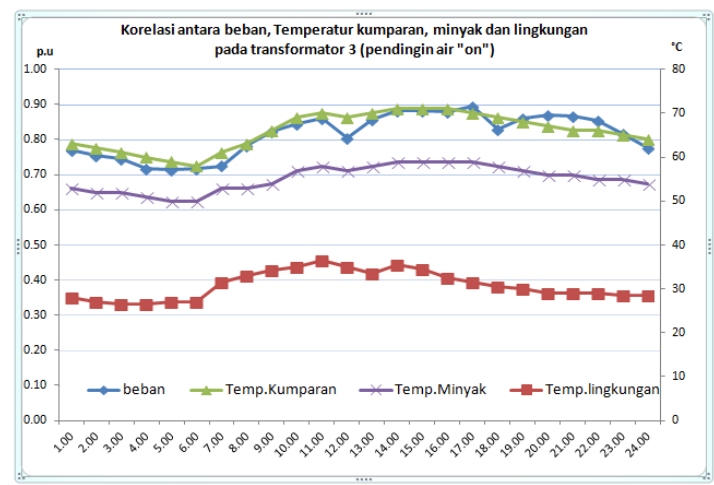

Gambar 4.1 Kurva Korelasi Antara Beban, Temperatur Kumparan, Minyak dan Lingkungan Pada Transformator 3 (Tanggal 08 November 2016)

Dari kurva diatas terlihat bahwa arah perubahan dari pergerakan temperatur lingkungan terhadap temperatur kumparan dan temperatur minyak tidak selalu kearah bersamaan. Ketika beban puncak pada 
siang hari kenaikan tertinggi hanya berkisar temperatur $70^{\circ} \mathrm{C}-71^{\circ} \mathrm{C}$.

Sedangkan pada saat beban puncak malam hari 0,87 p.u temperatur kumparan dan minyak tidak mengalami kenaikan dan kondisi temperatur tersebut mengalami penurunan, karena penurunan temperatur lingkungan dan beroperasinya penambahan pendingin transformator tersebut.

\subsection{Hasil Pengukuran Tanggal 09 November 2016}

Berikut adalah Data hasil pengukuran transformator unit 3 pada tanggal 09 November 2016 tanpa beroperasinya pendingin air.

\begin{tabular}{|c|c|c|c|c|c|c|c|c|c|c|c|c|}
\hline & 00 & 2.00 & 3.00 & 4.00 & 5.00 & 6.00 & 00 & 8.00 & 10 & .00 & .00 & T \\
\hline $\begin{array}{l}\text { Temp. } \\
\text { Lingkngan } \\
\left({ }^{\circ} \mathrm{C}\right)\end{array}$ & 27.5 & 27.0 & 26.0 & 26.0 & 26.5 & 27.0 & 32.0 & 33.0 & 34.5 & 35.0 & 36.0 & 36.5 \\
\hline $\begin{array}{l}\text { Kumpar } \\
\left({ }^{\circ} \mathrm{C}\right)\end{array}$ & 63 & 63 & 62 & 62 & 61 & 60 & 62 & 65 & 68 & 72 & 73 & 72 \\
\hline $\begin{array}{l}\text { Minuaxak } \\
\left({ }^{\circ} \mathrm{C}\right)\end{array}$ & 5 & 53 & 52 & 52 & 52 & 51 & 53 & 55 & 58 & 61 & 63 & \\
\hline $\begin{array}{l}\text { Beban } \\
\text { (MW) }\end{array}$ & & & & 42.50 & 42.05 & 2.05 & 43.75 & .55 & 48.55 & 9.85 & 1.00 & 48. \\
\hline $\begin{array}{l}\text { Beban } \\
\text { (Q., }\end{array}$ & 0.766 & 58 & 0.755 & 0.724 & 0.716 & 0.716 & 0.734 & 0.785 & 0.827 & 0.848 & 0.864 & 0.80 \\
\hline
\end{tabular}

\begin{tabular}{|c|c|c|c|c|c|c|c|c|c|c|c|c|}
\hline & 13.00 & 14.00 & 15.00 & 16.00 & $\begin{array}{l}17.00 \\
\end{array}$ & 18.00 & 19.00 & 20.00 & 21.00 & 222.00 & 23.00 & 24.00 \\
\hline $\begin{array}{l}\text { Temp. } \\
\text { Lingknogan } \\
\left({ }^{\circ} \mathrm{C}\right)\end{array}$ & 36.5 & 36.0 & 35.0 & 34.0 & 32.5 & 31.5 & 31.0 & 30.0 & 30.0 & 30.0 & 29.5 & 8.5 \\
\hline $\begin{array}{l}\text { Kumparan } \\
\left({ }^{\circ} \mathrm{C}\right)\end{array}$ & 72 & 73 & 73 & 7 & 72 & 71 & 71 & 70 & 69 & 69 & 68 & 67 \\
\hline $\begin{array}{c}\text { Minya) } \\
\left.{ }^{\circ} \mathrm{C}\right) \\
\end{array}$ & 62 & 63 & 6 & 63 & 62 & 62 & 62 & 60 & 60 & 59 & 58 & 57 \\
\hline $\begin{array}{l}\text { Eeban } \\
\text { (MW) }\end{array}$ & 51.50 & .5 & 52.5 & 52.0 & 52.55 & 49.50 & 50.50 & 51.50 & 51.25 & 51.00 & 48.50 & 46.45 \\
\hline $\begin{array}{l}\text { Beban } \\
(2, u)\end{array}$ & 360 & 0.887 & 0.888 & 0.886 & 0.895 & 0.835 & 0.865 & 0.877 & 0.873 & 0.869 & 0.818 & 0.7 \\
\hline
\end{tabular}

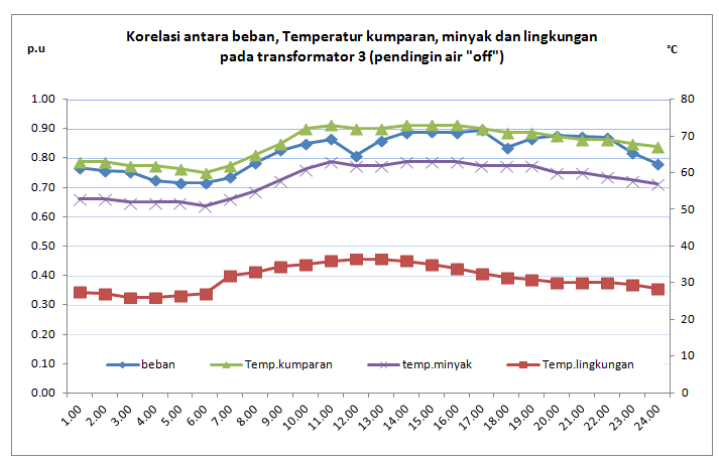

Gambar 4.2 Kurva Korelasi Antara Beban,

Temperatur Kumparan, Minyak dan

Lingkungan Pada Transformator 3 (Tanggal 09 November 2016)

Dari kurva diatas terlihat bahwa arah perubahan dari pergerakan temperatur lingkungan terhadap temperatur kumparan dan temperatur minyak berjalan bersamaan. Ketika beban puncak pada siang hari temperatur kumparan dan minyak juga mengalami kenaikan selaras dengan kenaikan beban. Pada saat beban puncak malam hari mencapai 0.89 p.u temperatur kumparan dan minyak masih selaras dengan pergerakan beban. Ketika temperatur lingkungan mengalami penurunan, pergerakan penurunan temperatur kumparan dan minyak berlangsung lebih lambat.

\subsection{Hasil Pengukuran Tanggal 15 November 2016}

Pengambilan data hasil pengukuran dilakukan pada hari kerja yang sama pada saat penambahan pendingin transformator menggunakan air. Hasil data pengukuran dilaksanakan pada hari Selasa, tanggal 15 November 2016 sebagai berikut :

\begin{tabular}{|c|c|c|c|c|c|c|c|c|c|c|c|c|}
\hline & 1.00 & \begin{tabular}{|l|l|}
2.00 \\
\end{tabular} & 00 & 4.00 & \begin{tabular}{|l}
5.00 \\
\end{tabular} & .00 & 7.00 & 8.00 & 9.00 & 0.00 & 11.00 & 2.00 \\
\hline $\begin{array}{l}\text { Temp. } \\
\text { Lingupngan } \\
\left.{ }^{\circ} \mathrm{C}\right)\end{array}$ & 28 & 27.5 & 27 & 27 & 26.5 & 27.5 & 32.5 & 34 & 34.5 & \begin{tabular}{|l|}
35.5 \\
\end{tabular} & 36 & \begin{tabular}{|l|l} 
\\
\end{tabular} \\
\hline $\begin{array}{l}\text { KumDPa } \\
\left({ }^{\circ} \mathrm{C}\right)\end{array}$ & 63 & 62 & 61 & 60 & 59 & 58 & 62 & 65 & 68 & 71 & 73 & \\
\hline $\begin{array}{l}\text { Minyak } \\
\left({ }^{\circ} \mathrm{C}\right)\end{array}$ & 53 & 53 & 52 & 51 & 50 & 49 & 54 & 56 & 58 & 61 & 63 & \\
\hline $\begin{array}{l}\text { Reban } \\
\text { (MW) }\end{array}$ & 45.44 & \begin{tabular}{|l|l}
44.87 \\
\end{tabular} & 44.87 & 16 & \begin{tabular}{|l|l}
43.11 \\
\end{tabular} & 42.82 & \begin{tabular}{|l}
44.36 \\
\end{tabular} & 47.13 & 50.52 & 51.70 & $\mid$\begin{tabular}{|l}
$\mid$ \\
3.07
\end{tabular} & $\begin{array}{l}49.6 \\
\end{array}$ \\
\hline $\begin{array}{l}\text { Bebana } \\
\text { (2.u) }\end{array}$ & 7774 & 0.756 & 0.756 & 727 & \begin{tabular}{|l|l}
0.727 \\
\end{tabular} & 0.722 & \begin{tabular}{|l|l|} 
& 0.748
\end{tabular} & 0.803 & $\mid 0.860$ & $\mid 0.880$ & \begin{tabular}{|l|l}
0.904 \\
\end{tabular} & 0.846 \\
\hline
\end{tabular}

\begin{tabular}{|c|c|c|c|c|c|c|c|c|c|c|c|c|}
\hline & 13.00 & \begin{tabular}{|l|l}
44.00 \\
\end{tabular} & \begin{tabular}{|l|l}
15.00 \\
\end{tabular} & \begin{tabular}{|l|l}
16.00 \\
\end{tabular} & 17.00 & \begin{tabular}{|l|l}
18.00 \\
\end{tabular} & \begin{tabular}{|l|l}
19.00 \\
\end{tabular} & 20.00 & \begin{tabular}{|l}
21.00 \\
\end{tabular} & 22.00 & 23.00 & \begin{tabular}{|l|l}
24.00 \\
\end{tabular} \\
\hline $\begin{array}{l}\text { Temp. } \\
\text { Lingknosan } \\
\left.\text { ( }{ }^{\circ} \mathrm{C}\right)\end{array}$ & 36.5 & 36.5 & \begin{tabular}{|l}
35.5 \\
\end{tabular} & 34 & 33 & 32 & 31 & 30.5 & \begin{tabular}{|l}
0.5 \\
\end{tabular} & 30 & 29.5 & 28.5 \\
\hline $\begin{array}{l}\text { Kumparan } \\
\left({ }^{\circ} \mathrm{C}\right)\end{array}$ & 72 & 73 & 73 & 73 & 72 & 71 & 71 & 70 & 69 & 69 & 68 & 67 \\
\hline $\begin{array}{l}\text { Minyak } \\
\left({ }^{\circ} \mathrm{C}\right)\end{array}$ & 63 & 63 & 63 & 63 & 62 & 61 & 61 & 60 & 60 & 59 & 58 & 57 \\
\hline $\begin{array}{l}\text { Beban } \\
\text { (MW) }\end{array}$ & 52.90 & \begin{tabular}{|l}
42.25 \\
\end{tabular} & 54.42 & 54.08 & 53.57 & 50.86 & 52.56 & 53.57 & |53.57 & 52.90 & 50.70 & 48.32 \\
\hline $\begin{array}{l}\text { Beban } \\
(p, v)\end{array}$ & 0.901 & 0.924 & $\mid 0.927$ & 0.921 & 0.912 & 0.866 & 0.895 & 0.912 & 0.912 & 0.901 & 0.855 & 0.823 \\
\hline
\end{tabular}

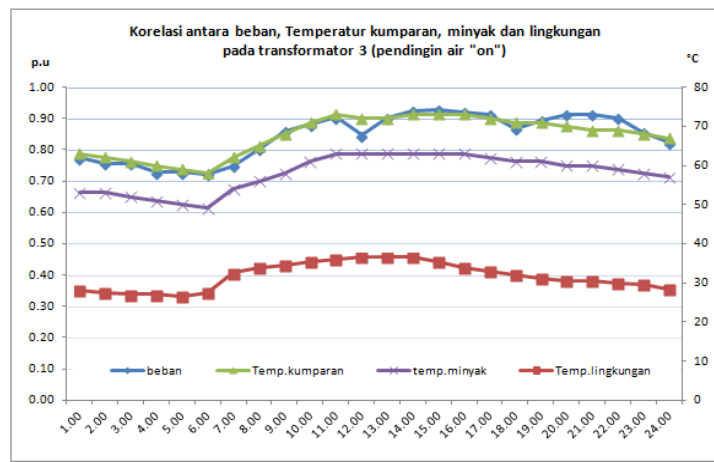

Gambar 4.3 Kurva Korelasi Antara Beban,

Temperatur Kumparan, Minyak Dan Lingkungan Pada Transformator 3 (Tanggal 15 November 2016)

Dari kurva diatas terlihat perbedaan yang signifikan dengan pengukuran tanggal 09 November 2016 adalah pada jam 24.00, ketika beban 0,82 p.u temperatur kumparan $67^{\circ} \mathrm{C}$ (tidak ada perbedaan). Akan tetapi perbedaan terlihat pada pembebanan yaitu selisih 2,51 MW. 


\subsection{Hasil Pengukuran Kecepatan Angin dan Kelembaban di GI Marunda}

Berikut adalah hasil pengukuran kecepatan angin disekitar transformator unit 3 :

1) Kondisi beroperasi dengan menggunakan pendingin udara secara paksa (Fan) dan dengan penambahan pendingin air, tanggal 08 November 2016.

2) Kondisi beroperasi dengan menggunakan pendingin udara secara paksa (Fan) tanpa penambahan pendingin air, tanggal 09 November 2016.

\begin{tabular}{|l|c|c|c|c|}
\hline \multirow{3}{*}{$\begin{array}{l}\text { Posisi Dinding } \\
\text { Transformator }\end{array}$} & \multicolumn{4}{|c|}{ Kecepatan Angin ( $\mathrm{m} / \mathrm{s}$ ) } \\
\cline { 2 - 5 } & 1 & 2 & 1 & 2 \\
\cline { 2 - 5 } & 0.25 & 0.25 & 0.40 & 0.40 \\
\hline Belakang & 0.40 & 0.40 & 0.50 & 0.50 \\
\hline Bawah & 0.35 & 0.35 & 0.50 & 0.50 \\
\hline Depan & 0.25 & 0.25 & 0.35 & 0.34 \\
\hline Kiri & 0.25 & 0.25 & 0.45 & 0.45 \\
\hline Kanan & 0.55 & 0.50 & 1.5 & 1.5 \\
\hline Atas & & & & \\
\hline Sumber: Hasil Pengukuran & &
\end{tabular}

\begin{tabular}{|c|c|c|c|}
\hline \multirow{2}{*}{ Area Marunda } & \multicolumn{2}{|c|}{ Kecopatan Angin (m/s) } & Kelembaban (\%) \\
\cline { 2 - 4 } & Minimum & Maksimum & Rata-rata \\
\hline Tanggal 08/11/2016 & 0.51 & 2.06 & 80 \\
\hline Tanggal 09/11/2016 & 1.03 & 2.57 & 77 \\
\hline Tanggal 15/11/2016 & 1.05 & 2.62 & 78 \\
\hline
\end{tabular}

\subsection{Hasil Pengukuran Penggunaan Air dan Temperatur Air pada Tanggal 08 November 2016.}

Berikut adalah hasil pengukuran air dan nilai penggunaan air secara konstan pada transformator unit 3 .
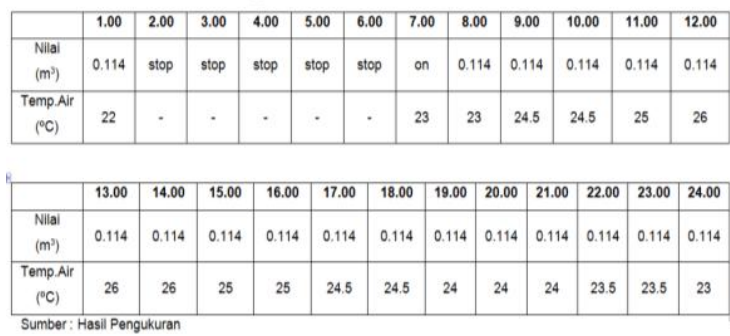

Dari data diatas rata-rata penggunaan air adalah $0.114 \mathrm{~m}^{3}$ per jam (dalam waktu 18 jam), sehingga total penggunaan air dalam 18 jam operasi adalah 2,052 $\mathrm{m}^{3}$.

\subsection{Hasil Perhitungan Laju Hilangnya \\ Panas pada Permukaan Atas \\ Transformator terhadap \\ Pengukuran Menggunakan Infrared (Thermovisi)}

Diketahui data sebagai berikut :

Koefisien perpindahan panas minyak, didalam $\left(h_{1}\right)=1800$

Koefisien perpindahan panas air, diluar $\left(h_{2}\right)=170$

Tebal plat bagian atas $=13 \mathrm{~mm}$

Konduktivitas thermal baja $(k)=50 \mathrm{~W} / \mathrm{m}$. $\mathrm{K}$

Dengan menggunakan persamaan ( $2-5)$

$$
\begin{aligned}
\frac{1}{U} & =\left(\frac{1}{h_{1}}+\frac{x}{k}+\frac{1}{h_{2}}\right) \\
& =\left(\frac{1}{1800}+\frac{13}{10^{3} \times 50}+\frac{1}{170}\right) \\
& =0.000555+0.00026+0.00589 \\
& =0.00670
\end{aligned}
$$

Dengan mengambil data temperatur kumparan, pada tanggal 08 November 2016, yaitu pada jam 08.00 sebesar $63^{\circ} \mathrm{C}$ dan temperatur air jam 08.00 adalah $23^{\circ} \mathrm{C}$.

Maka dengan menggunakan persamaan (2-3), didapat :

$q=U\left(t_{A}-t_{B}\right)=\left(\frac{63-23}{0.00670}\right)=5.972 \mathrm{~W}$ $/ \mathrm{m}^{2}$

Laju hilangnya panas per meter persegi dari luas permukaan bagian atas transformator adalah $5.97 \mathrm{~kW}$

Dari persamaan (2-2)

$q=h_{2}\left(t_{2-} t_{B}\right) 5.972=170 \times\left(t_{2-} 23\right)$

$t_{2}$ adalah temperatur permukaan luar bagian atas dari transformator (seperti terlihat pada gambar 2.2)

$$
t_{2}=\left(\frac{5.972}{170}+23\right)=58,12^{\circ} \mathrm{C}
$$

Jadi temperatur permukaan luar bagian atas dari transformator pada jam 08.00 adalah $58.12^{\circ} \mathrm{C}$.

Hasil pengukuran temperatur kumparan dipilih untuk perhitungan karena menunjukkan nilai terpanas didalam transformator, lalu dimasukkan kedalam persamaan-persamaan didapat nilai sebagai berikut : 

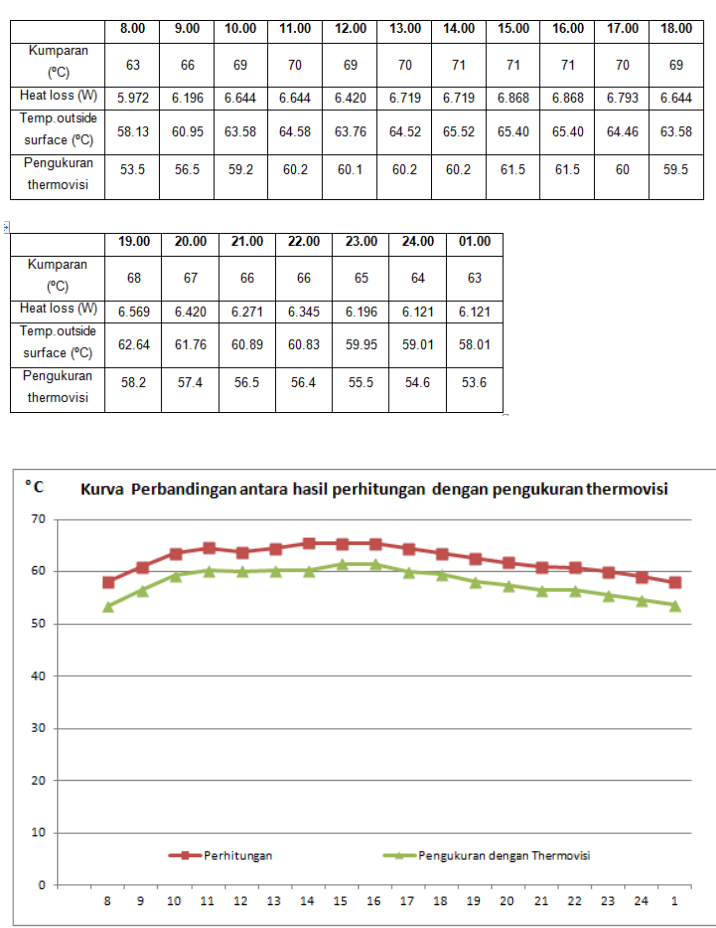

Gambar 4.4 Kurva Perbandingan Perhitungan Laju Hilangnya Panas dan Temperatur Bagian Luar Pada Permukaan Atas Tangki Transformator dengan Pengukuran Thermovisi.

Dari kurva diatas terlihat bahwa arah perubahan dari pergerakan temperatur permukaan atas transformator linear antara perhitungan temperatur permukaan atas dengan pengukuran menggunakan thermovisi pada transformator kearah bersamaan terhadap waktu. Ketika beban puncak pada siang hari jam 15.00 merupakan temperatur terpanas pada permukaan atas transformator menggunakan thermovisi, karena pada waktu itu temperatur lingkungan juga tinggi, sehingga ada kenaikan pada temperatur permukaaan atas pada transformator.

\section{KESIMPULAN}

Penelitian ini menunjukkan bahwa dengan menggunakan air sebanyak 114 liter/jam, temperatur kumparan dan minyak tertinggi dapat diturunkan sebesar $3^{\circ} \mathrm{C}$, yang dapat menambah pembebanan transformator sebesar 2,51MW. Sedangkan laju hilangnya panas rata-rata per jam adalah $6,47 \mathrm{~kW} / \mathrm{m}^{2}$.
Penambahan pendingin air pada transformator daya berguna untuk meredam efek dari pengaruh temperatur lingkungan yang tinggi. Hasil penelitian menunjukkan bahwa ketika temperatur lingkungan tinggi maka temperatur kumparan dan minyak didalam transformator akan terpengaruh, berbanding lurus dengan naik turunnya beban. Ketika temperatur air diatas batas yang direkomendasikan yaitu $25^{\circ} \mathrm{C}$, laju hilangnya panas lebih rendah dari pada nilai dibawah batas yang direkomendasikan.

\section{REFERENSI}

1. Assuncao, T. C. B. N., Silvino, J. L., Resende., P. (2006). Transformer Top-Oil Temperature Modeling and Simulation. Journal of transactions on engineering, computing and technology volume $15,240-245$.

2. Min-gu Kim, Sang M.C, Kim, J.K. (2012). Prediction and evaluation of the cooling performance of radiators used in oil-filled power transformer applications with non-direct and direct-oil-forced flow" Journal of Experimental Thermal and Fluid Science

3. Susa, D. (2005). Dissertations : Dynamic Thermal Modelling of Power Transformers. Helsinki : Department of Electrical and Communications Engineering.

4. T.D Eastop, McConkey. (2009). Applied Thermodynamics for Engineering Technologists (5th Edition).

5. Cholil, M. Suprapto, \& Suyamto. (2012). Desain Sistem Pendingin Pada Transformator Frekuensi Tinggi Pada Mesin Berkas Elektron 300 $\mathrm{keV} / 20 \mathrm{~mA}$. Jurnal batan Vol.14

6. Institute of Electrical and Electronic Engineers. 1995. IEEE Guide for Loading Mineral-Oil Immersed Power Transformers. IEEE Standard C57.91. Author, New York, New York, USA.

7. Perez Joe, (2010). Fundamental Principles Of Transformer Thermal Loading And Protection. Journal of ERLPhase Power Technologies 
8. Loading Guide for Oil-immersed Power Transformers; IEC 60076-7; International Electrotechnical Commission (IEC) : Geneva, Switzerland, 2007.

9. PLN. (2014). Buku Pedoman Petunjuk Pemeliharaan Transformator. SK.Dir 114.

10. Krisnadi, D. I. (2011). Tesis: Analisis Pengaruh Temperatur Terhadap
Masa Guna Dan Pembebanan Darurat Transformator Daya. Depok : Fakultas Teknik Elektro Universitas Indonesia.

11. Heathcote, Martin J., (1998) The J\&P Transformer Book, Newnes, Great Britain. 